ДОСЛІДЖЕННЯ СТРЕСОСТІЙКОСТІ СТУДЕНТІВ-ПСИХОЛОГІВ ПЕРШОГО КУРСУ З РІЗНИМИ РІВНЯМИ ТРИВОЖНОСТІ ТА ТИПАМИ ТЕМПЕРАМЕНТУ

\title{
RESEARCH OF STRESS RESISTANCE OF FIRST COURSE STUDENTS-PSYCHOLOGISTS WITH DIFFERENT LEVELS OF ANXIETY AND TYPES OF TEMPERAMENT
}

УДК 159.9.07

DOI https://doi.org/10.32843/2663-

5208.2021.30.16

\section{Даниленко Н.В.}

к.психол.н., доцент,

доцент кафедри психології

Харківський національний педагогічний університет імені Г.С. Сковороди

\section{Сулім В.O.}

магістрантка кафредри психології Харківський національний педагогічний університет імені Г.С. Сковороди у статті розглядається проблема стресостійкості студентів-психологів першого курсу та особливості їхнього темпераменту і тривожності. Зазначено, що вступ до ВНЗ та подальше навчання $є$ стресогенним фрактором, що впливає на психоемоційний стан студента, тому розгляд даної проблеми є важливим і актуальним. Проаналізовано фрахову літературу на тему стресостійкості, темпераменту та тривожності. Відмічено, що питання стресостійкості розкривається в багатьох роботах фахівців, але за умов пандемії COVID-19 виникає потреба у нових дослідженнях даної проблеми з приділенням уваги особистісним характеристикам студентів. Для проведення дослідження обрано такі методики: «Особистісний опитувальник» Г. Айзенка (EPQ) для визначення типу темпераменту (типологія за Г. Суходольським); «Особистісна шкала проявів тривоги» Тейлора; «Тест на визначення рівня стресостійкості» (за О. Пахомовим). За підсумками дослідження бачимо, що 3 дев'яти типів особистостей за темпераментом в досліджуваній групі були виявлені представники лише п'яти типів. Найбільша кількість респондентів належить до нормального та холерико-сангвінічного типів темпераменту. Більшість досліджуваних має середній рівень тривоги з тенденцією до високого рівня чи високий рівень тривоги, решта - середній рівень з тенденцією до низького рівня тривоги. У ході дослідження не визначено жодного респондента з високим рівнем стресостійкості чи з низьким. $У$ всіх досліджуваних простежується середній рівень стресостійкості (у більшості з тенденцією до високого рівня стресостійкості, у меншості - до низького рівня). Подальшу роботу автори вважають за потрібне присвятити встановленню наявності взаємозв'язку між рівнем стресостійкості та типом темпераменту ірозробці рекомендацій щодо підвищення рівня стресостійкості. Ключові слова: дослідження, студенти, стрес, стресостійкість, рівень стресостій- кості, тип темпераменту, рівень тривоги, тривожність.

The article considers the problem of stress resistance of first-year psychologists and features of their temperament and anxiety. It is noted that admission to higher education and further education is a stressful factor that affects the psycho-emotional state of the student, and therefore consideration of this issue is important and relevant. The professional literature on stress resistance, temperament and anxiety was analyzed. It is noted that the issue of stress resistance is revealed in many works of specialists, but in the context of the COVID-19 pandemic there is a need for new research on this issue, paying attention to the personal characteristics of students. The following methods were chosen for the study: "Eysenck Personality Questionnaire $(E P Q)$ to determine the type of temperament (typology according to G. Sukhodolsky)"; "Teilor's Manifest Anxiety Scale" and "Test to determine the level of stress resistance (according to O. Pakhomov)". According to the results of the research, we see that of the nine types of personalities in temperament in the study group, there are only five types. The largest percentage of respondents belongs to the normal and choleric-sanguine types of temperament. Most subjects have an average level of anxiety with a tendency to a high level or a high level of anxiety, the rest a medium level with a tendency to a low level of anxiety. The research did not identify any respondents with either a high level of stress resistance or a low level of stress resistance. All subjects have an average level of stress resistance - the majority of respondents with a tendency to a high level, a minority of subjects - with a tendency to a low level of stress resistance. Further work in the research, the authors consider it necessary to devote to establishing the relationship between the level of stress resistance and the type of temperament and the development of recommendations for improving the level of stress resistance. Key words: research, students, stress, stress resistance, stress resistance level, temperament type, anxiety level, anxiety.
Вступ до вищого навчального закладу $€$ вагомим стресогенним фактором, що впливає на психоемоційний стан студента. Найчастіше це пов'язано з потребою в адаптації до нового ритму життя, зі зміною кола спілкування, а також з особливостями проживання в новому місті чи умовах гуртожитку. Великий обсяг інформації, висока інтенсивність занять, підготовка та переживання з приводу майбутніх заліків та іспитів - усе це вимагає мобілізації всіх внутрішніх ресурсів організму. Якщо емоційне напруження виявляється тривалим, воно легко може перерости в затяжний і навіть хронічний стрес. Отже, проблема навчального стресу та питання стресостій- кості у студентів є досить актуальними. Особливо ця проблема загострилася у зв'язку із пандемією COVID-19, яка внесла суттєві зміни в звичний процес навчання.

Стресом називають неспецифічний стан або реакцію організму на різні несприятливі чинники (стресори), що впливають на нього.

У психології виділяють позитивну (еустрес) і негативну (дистрес) форми стресу. У результаті еустресу підвищується функціональний резерв організму, відбувається його адаптація до стресового фактору. У разі дистресу людина проявляє дезадаптивну поведінку і не може повністю адаптуватися до стресових ситуацій та спричинених ними наслідків. 
Яким би не був стрес - позитивним чи негативним, емоційним або фізичним, вплив його на організм має загальні неспецифічні риси $[1$, c. 7].

Вперше термін «стрес» у психологію і фізіологію ввів американський психофізіолог Уолтер Бредфорд Кеннон у своїх класичних роботах з універсальної реакції «бий або біжи».

Канадський фізіолог Г. Сельє у 1936 році опублікував свою першу роботу з загального адаптаційного синдрому, але тривалий час уникав вживання терміна «стрес», оскільки той використовувався переважно для позначення нервово-психічної напруги. Тільки у 1946 році Г. Сельє почав використовувати термін «стрес» для позначення загальної адаптаційної напруги [2, с. 15].

Окрім Г. Сельє, який розробив і довів універсальну концепцію стресу, дослідженнями в цій галузі займалася велика кількість вчених. Дж. Мейсон аналізував теорію стресу. Вивченням психологічного боку стресу займалися такі видатні вчені, як Ж. Годфруа, І.С. Кон, Б.М. Коган, С.Л. Рубінштейн, К.В. Судаков та ін. Питання поведінки людей в екстремальних ситуаціях вивчали такі представники психології праці: Л.Г. Дика, М.Н. Дьяченко, Л.Н. Захарова, В.В. Собольніков та ін.

Американським психологом Р. Лазарусом і групою дослідників був проведений експеримент для вивчення впливу когнітивної оцінки ситуації загрози на формування стресової реакції. На основі результатів даного дослідження Р. Лазарусом і його колегами була розроблена теорія психологічного стресу, яка стоїть на одному рівні значущості для науки з концепцією стресу Г. Сельє [2, с. 21].

Важливою особливістю психологічного стресу, яка відрізняє його від біологічного стресу, описаного в класичних роботах Г. Сельє, є спроможність запускатися не тільки реальними, але і ймовірними подіями, які ще не відбулися, але настання яких бентежить чи лякає суб'єкта. Наприклад, у студента лише думки про ймовірну незадовільну оцінку часом викликають сильніші вегетативні реакції, ніж їі отримання на іспиті.

Чинники, що викликають стрес, можуть бути різними, але всі вони викликають однакову біологічну реакцію стресу.

Численні дослідження в галузі фізіології стресу виявили, що стрес завжди розвивається за однією схемою, яка була побудована в ході еволюції. Сигнали від загрозливих подразників надходять в мозок. Далі мозок сигналізує про небезпеку, посилюючи гормональну активність і активність вегетативної нервової системи, що веде до перерозподілу енергетичного потенціалу організму. Необхідність цього перерозподілу полягає в тому, щоб збільшити приплив енергії до мозку і м'язів за рахунок ослаблення статевої, харчової та імунної систем. Також під час стресу відбуваються зміни інтелектуальних процесів людини, в тому числі страждають такі базові властивості інтелекту, як пам'ять і увага.

Аналізуючи літературу на тему стресу та стресостійкості, ми помітили, що серед найбільш значущих чинників, що впливають на стійкість до стресів, багатьма українськими фахівцями і дослідниками виділяються показники тривожності. Тривожність як психологічне відображення стресу згадується в роботі «Психологія стресу» [3, с. 47]. Вплив особистісної та реактивної тривожності на розвиток стресостійкості підкреслюється в роботі «Стресостійкість студентів як складник успішності навчання у ЗВО» [4].

На базі Одеського національного медичного університету було проведене дослідження, присвячене питанням стресостійкості і тривожності та їх впливу на рівень захворюваності на ГРЗ у студентів I і IV курсів [5].

Отже, в нашому дослідженні під час визначення рівня стресостійкості ми також аналізували рівень тривоги респондентів як важливу складову частину цього параметру.

Тривога - це емоційне переживання, за якого людина відчуває дискомфорт від невизначеності перспективи. Помірна тривога допомагає мобілізувати сили, привертає увагу до вирішення певної ситуації. Коли рівень тривоги суттєво підвищується, а занепокоєння стає постійним, настирливим та віднімає багато сил, то психологи називають такий стан тривожним розладом або підвищеною тривожністю.

Тривожність - це індивідуальна психологічна особливість, що виявляється у схильності людини часто відчувати сильну тривогу, в тому числі й тоді, коли приводу для занепокоєння немає.

Багато вчених-психологів займалося дослідженням тривоги, намагаючись з'ясувати причини її виникнення та методи боротьби з нею. Наприклад, 3. Фрейд приділяв тривожності в своїх роботах особливу увагу як одній з фундаментальних і найважливіших проблем людини.

Неофрейдисти, зокрема К. Хорні, називали одним з головних чинників, що впливають на виникнення тривожності, середовище, в якому росте дитина, зокрема її взаємини з батьками.

Американський психолог і психіатр Г. Салліван вважав, що якщо людина часто стикається з несхваленням важливих дня неї людей, то це з великою імовірністю може викликати в неї тривожний розлад.

Психологи екзистенційно-гуманістичного спрямування Р. Мей і С. Мадді говорили про те, що позбутися тривоги неможливо, майбутнє завжди пов'язане з невизначеністю та ризи- 
ком, тому коли ми вчимося робити вибір, рухатися в майбутне, то ми вчимося конструктивно підходити до своєї тривоги.

Сьогодні в багатьох країнах світу можна спостерігати феномен соціальної тривожності, пов'язаний з пандемією COVID-19. Соціальна тривожність супроводжує всі глобальні кризи і часто приймає масовий характер.

Згідно зі звітом Американської психологічної асоціації за 2021 рік у жителів США спостерігається рекордний рівень стресу і тривожності. Також про високий рівень стресу у європейців ідеться в іншому дослідженні, опублікованому в січні 2021-го року в авторитетному медичному журналі “Lancet”. Причиною такого стану $є$ страх перед вірусом, соціальною ізоляцією, тривога за рідних та близьких, ризик втратити роботу і обмеження на подорожі та розваги. Результатом цього стає зростання рівня алкоголізму, неврологічні розлади (зокрема, ОКР), серцевосудинні захворювання і соціальна тривога.

Проблема в тому, що довгоочікуване зняття обмежень призводить до нового піку соціального тривожного розладу. Звикнувши до обмежень, багато хто відчуває страх перед масовим скупченням людей, роботою в офісі, громадським транспортом, контактами зі сторонніми людьми та брудними поверхнями. Як стверджує CNN, через це багато людей не може повернутися до нормального життя.

Дослідники з Оксфордського університету, вивчивши 70 млн медичних карт американців, з'ясували, що у 18\% тих, хто перехворів на COVID-19, спостерігаються безсоння, тривога і депресія (у 5,8\% ці симптоми були виявлені вперше) [6].

У своєму дослідженні ми висунули гіпотезу про те, що, окрім рівня тривоги, на рівень стресостійкості впливає тип темпераменту людини.

Темперамент - це сукупність вроджених особливостей людини, які зумовлюють динамічні характеристики інтенсивності та швидкості реагування, ступінь емоційної збудливості і врівноваженості, особливості пристосування до середовища.

У різні часи висувалися різні гіпотези відносно основ темпераменту. Найбільшого розповсюдження набула нервова теорія І.П. Павлова, згідно 3 якою темперамент людини пояснюється особливостями функціонування центральної нервової системи, типами вищої нервової діяльності. І.П. Павлов пов'язав типи темпераменту, виділені Гіппократом, із загальними властивостями нервових процесів і довів, що кожна людина володіє вродженим типом нервової системи, який не змінюється протягом життя.

Темперамент формується 3 окремих властивостей нервової системи, серед яких І.П. Павлов виділив:
- силу нервової системи (витривалість нервових клітин, тобто їх здатність витримувати тривале збудження, не переходячи в стан гальмування);

- врівноваженість нервових процесів (співвідношення процесів збудження і гальмування нервової системи);

- рухливість нервових процесів (здатність нервових клітин швидко переходити від стану збудження до стану гальмування і навпаки) [7, с. 72].

Залежно від комбінації цих властивостей Павлов виділив чотири типи темпераменту. Так, сангвінік має сильний, урівноважений, рухливий тип нервової системи; холерик сильний, неврівноважений; флегматик - сильний, урівноважений, інертний; меланхолік слабкий, інертний тип нервової системи.

Відповідно до завдань нашого дослідження було вирішено провести тестування студентів першого курсу за трьома ознаками - типом темпераменту, рівнем тривоги і рівнем стресостійкості, а також проаналізувати отримані дані.

Для проведення дослідження були обрані такі методики:

1. «Особистісний опитувальник»Г. Айзенка (EPQ) для визначення типу темпераменту.

2. «Особистісна шкала проявів тривоги» Тейлора (Teilor's Manifest Anxiety Scale).

3. «Тест на визначення рівня стресостійкості» (за О. Пахомовим).

4. «Особистісний опитувальник» Г. Айзенка призначений для вивчення індивідуальнопсихологічних рис особистості з метою діагностики ступеня вираженості властивостей, висунутих в якості істотних компонентів особистості. Це такі властивості: нейротизм, екстра-інтроверсія і психотизм. Зазначений опитувальник передбачає визначення приналежності людини до одного з типів темпераменту з використанням поєднання ступеня вираженості екстраверсії та нейротизму.

Беручи дані $з$ фізіології вищої нервової діяльності, Г. Айзенк висунув таку гіпотезу: сильний і слабкий типи (за І.П. Павловим) $€$ близькими до екстравертивного та інтровертивного типів особистості. Природа інтроверсії та екстраверсії вбачається у вроджених властивостях центральної нервової системи, які забезпечують врівноваженість процесів збудження і гальмування.

Таким чином, використовуючи дані обстеження за шкалами екстраверсії, інтроверсії і нейротизму, можна вивести показники темпераменту особистості за класифікацією І.П. Павлова, який описав чотири класичних типи - сангвінічний, холеричний, флегматичний, меланхолічний.

Оскільки в житті в чистому вигляді такі типи темпераменту трапляються вкрай рідко, то слід говорити про перевагу тих чи інших рис 
темпераменту. Саме тому Г.В. Суходольський вважає за необхідне виділяти дев'ять типів особистості, а саме: норму і вісім акцентуацій - чотири «чистих» типи і чотири «проміжних» - холерико-сангвінічний, сангвінікофлегматичний, флегматико-меланхолічний та меланхолічно-холеричний.

На думку Г.В. Суходольського, типологію Г. Айзенка можна представити у вигляді матриці (таблиця 1).

Шкала «екстраверсія - інтроверсія» в концепції Г. Айзенка належить до базових рис особистості і характеризує такі психічні властивості, як товариськість - замкнутість, оптимізм - песимізм, зарозумілість - сором'язливість, імпульсивність - розсудливість в діях.

Шкала «нейротизм - емоційна стабільність» фіксує афективну збудливість чи емоційно-вольову стабільність, стійкість - нестійкість, властиву людині в тій чи іншій мірі залежно від вегетативної нервової системи, що відповідає за поведінку в стресі, виникнення агресії або тривоги.

Шкала «психотизм» виявляє схильність до асоціальної поведінки, високої конфліктності, неадекватності емоційних реакцій, неконтактності, байдужості та егоцентричності.

Кожному типу особистості відповідають такі зовнішні прояви:

- холерик (X) - агресивний, імпульсивний, запальний, легко змінює свої погляди;

- холерико-сангвінічний (XC) тип - оптимістичний, товариський, активний, екстравертивний;

- сангвінік (C) - невимушений, жвавий, має високу швидкість реакцій, говіркий;

- сангвініко-флегматичний (СФ) тип - врівноважений, безтурботний, стабільний, лідируючий, спокійний;

- флегматик (Ф) - надійний, миролюбний, розсудливий, вміє володіти собою;

- флегматико-меланхолічний (ФМ) тип старанний, пасивний, нетовариський, тихий, інтровертивний;

- меланхолік (М) - вразливий, песимістичний, боязкий, ригідний;

- меланхолічно-холеричний (MX) тип примхливий, нейротичний, сумлінний, легко ображається, неспокійний;

- нормальний тип $(\mathrm{H})$ - відносна норма особистості, за якої жоден з типів темпераменту не має яскравого вираження.
У нашому дослідженні ми спиралися на типологію особистості Г.В. Суходольського.

Аналіз шкал «екстраверсія - інтроверсія» та «нейротизм - емоційна стабільність» дозволяє зробити висновок відносно типу темпераменту кожного досліджуваного на підставі опитувальника Г.Ю. Айзенка.

Дамо характеристику отриманим результатам. 3 дев'яти описаних типів темпераменту в досліджуваній групі були виявлені представники лише п'яти типів, а саме:

- холерико-сангвінічного типу (26,2\%);

- флегматико-меланхолічного типу (2,3\%);

- меланхолічно-холеричного типу $(19,1 \%) ;$

- нормального типу (33,3\%);

- холерики (19,1\%).

Також завданням нашого дослідження було визначення рівня стресостійкості респондентів. Вище було зазначено, що важливою характеристикою особистості, що може суттєво впливати на рівень стресостійкості, Є рівень тривоги. Отже, наступним кроком $€$ оцінка рівня тривоги досліджуваних за допомогою тесту «Особистісна шкала проявів тривоги» за Тейлором. Проведемо аналіз цього показника в кожного типу темпераменту.

Тест «Особистісна шкала проявів тривоги» Тейлора (Teilor's Manifest Anxiety Scale) призначена для вимірювання проявів тривожності. У нашому дослідженні ми використовуємо варіант методики в адаптації Т.А. Немчинова.

у психологічному феномені тривожності вчені виділяють дві складові частини - реактивну тривожність і особистісну тривожність.

Реактивна тривожність пов'язана з безпосередньо пережитими емоціями, такими як нервозність, динамічна напруга, занепокоєння тощо. Така тривожність виникає внаслідок емоційної реакції організму на певну стресову ситуацію і характеризується різною інтенсивністю. Оскільки вимірювання реактивної тривожності обмежується конкретним моментом, з часом її рівень змінюється залежно від того, як людина розцінює своє оточення.

Особистісна тривожність - це стійка індивідуальна характеристика людини, яка відображає її схильність до тривоги і передбачає наявність у неї тенденції сприймати досить широкий перелік об'єктивно безпечних ситуацій як загрозливі, відповідаючи на кожну з таких реакцій підвищенням реактивної тривожності. Високий показник рівня особистіс-

Матрична типологія особистостей за методикою Г. Айзенка EPQ

Таблиця 1 (за Г. Суходольським)

\begin{tabular}{|l|c|c|c|}
\hline & $\begin{array}{c}\text { Інтроверсія } \\
\text { (<7 балів) }\end{array}$ & $\begin{array}{c}\text { Середнє значення } \\
\text { (7-15 балів) }\end{array}$ & $\begin{array}{c}\text { Екстраверсія } \\
\text { (> 15 балів) }\end{array}$ \\
\hline Нейротизм (>16 балів) & $\mathrm{M}$ & $\mathrm{MX}$ & $\mathrm{X}$ \\
\hline Середне значення $(8-16$ балів) & $Ф \mathrm{M}$ & $\mathrm{H}$ & $\mathrm{XC}$ \\
\hline Стабільність $(<8$ балів) & $\Phi$ & $\mathrm{CФ}$ & $\mathrm{C}$ \\
\hline
\end{tabular}




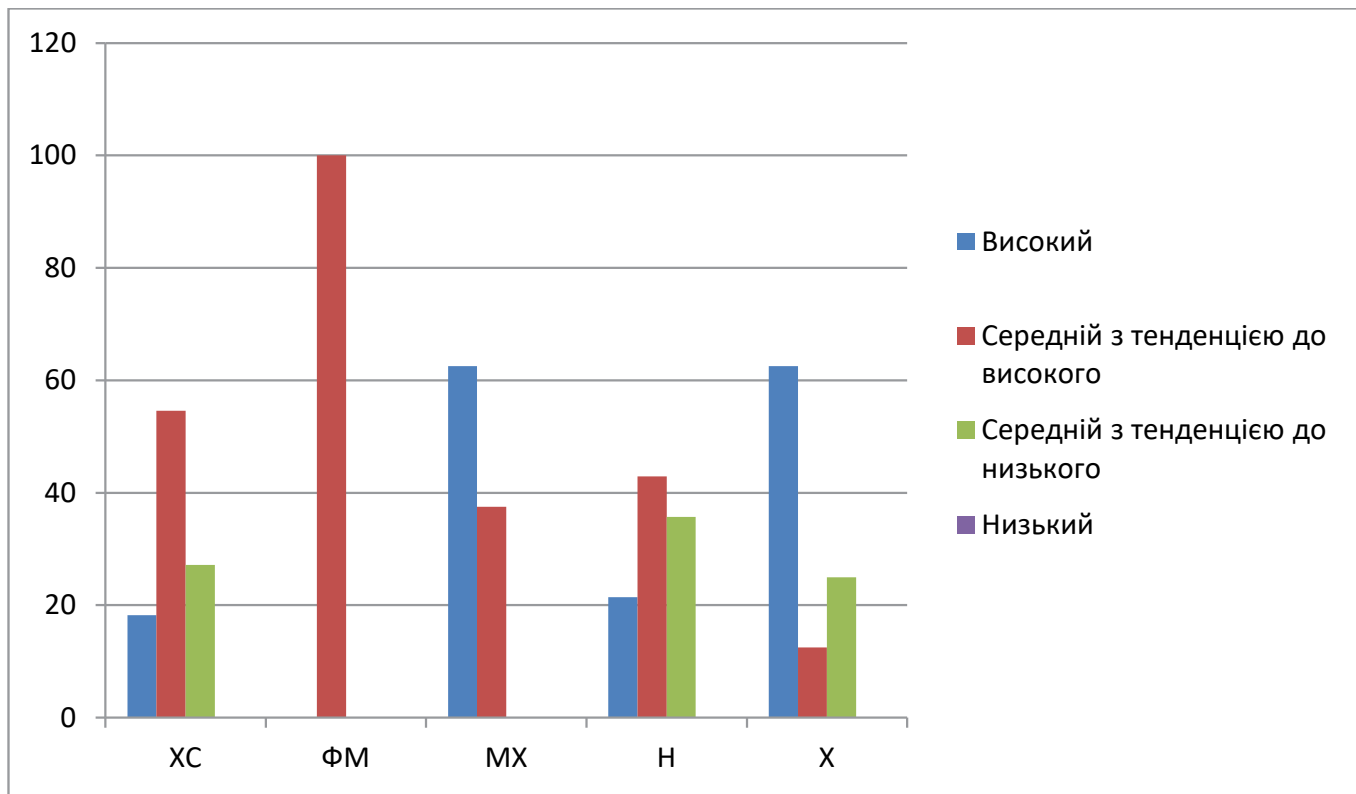

\section{Рис. 1. Графічне зображення рівнів тривоги за типами темпераменту (\%)}

ної тривожності вказує на те, що інтенсивність переживань суб'єкта часто не відповідає величині реальної небезпеки і характеризує минулий досвід індивіда, тобто те, наскільки часто йому доводилося відчувати стан реактивної тривоги.

За результатами тесту виявлено, що доосліджуваних студентів першого курсу переважає середній рівень тривоги з тенденцією до високого рівня. Трохи менше, але все одно багато респондентів має високий рівень тривоги, що може вказувати на особистісну тривожність.

Дуже висока особистісна тривожність може свідчити про наявність невротичного конфлікту, який у несприятливих умовах здатний спровокувати емоційні зриви і навіть психосоматичні захворювання.

Далі розглянемо окремо показники рівнів тривоги за типами темпераменту (рис. 1).

Отже, підсумовуючи отримані результати, бачимо, що найвищі показники за рівнем тривоги були виявлені у меланхолічно-холеричного типу і холериків (по 62,5\%), а досліджувані з середнім рівнем тривоги з тенденцією до низького рівня володіли нормальним типом (35,7\%).

Наступним етапом дослідження було визначення стресостійкості респондентів. Для цього ми використали тест на визначення рівня стресостійкості (за О. Пахомовим).

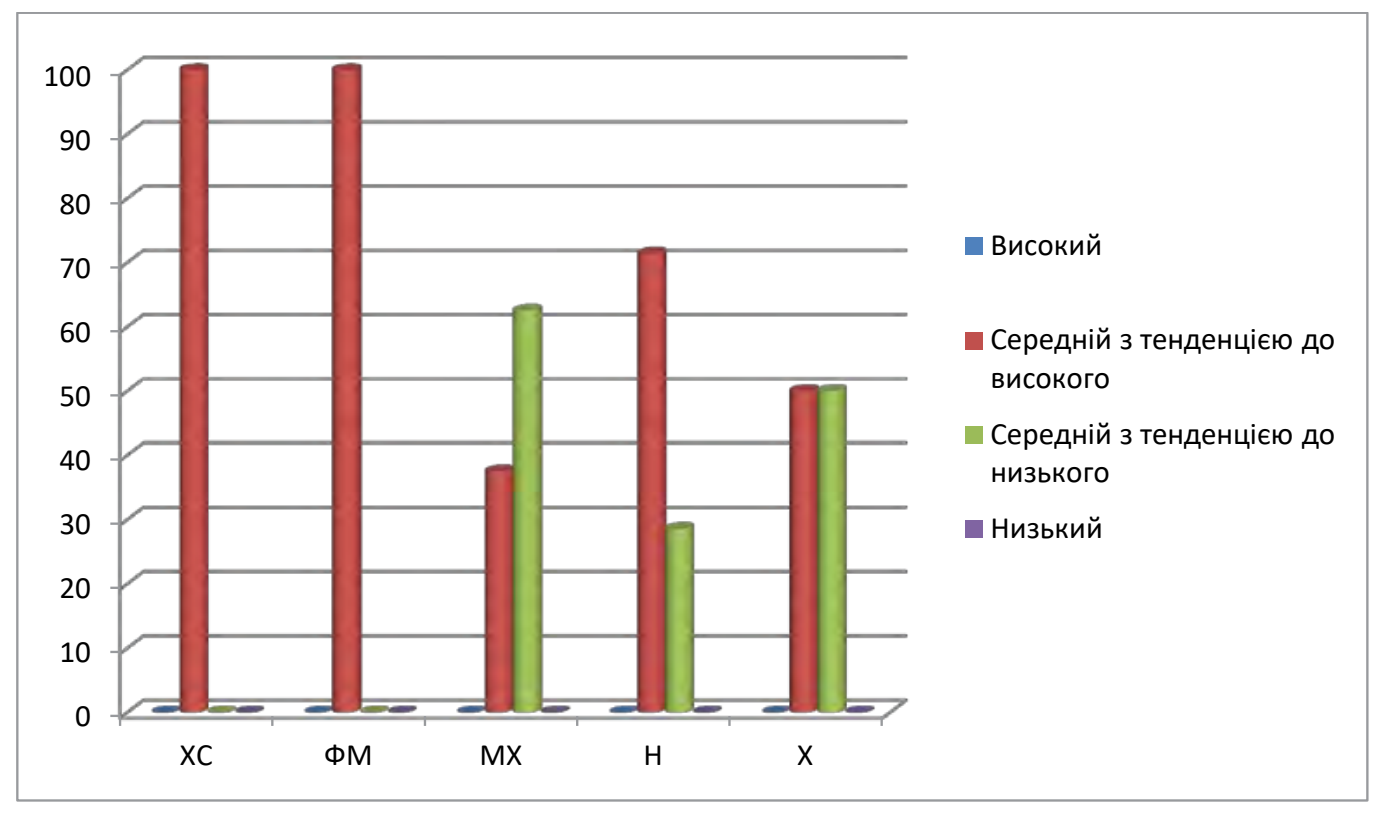

Рис. 2. Графічне зображення рівнів стресостійкості за типами темпераменту (\%) 
Результати тесту показали, що жоден з досліджуваних не має високого рівня стресостійкості, але й показники низького рівня теж не були виявлені. Отже, всі досліджувані мають середній рівень стресостійкості - одні з тенденцією до низького, інші з тенденцією до високого рівня.

Далі розглянемо окремо показники рівнів стресостійкості відносно типу темпераменту (рис. 2).

Тест на стресостійкість виявив, що найбільший відсоток досліджуваних 3 середнім рівнем стресостійкості з тенденцією до високого рівня простежується у холерико-сангвінічного та флегматико-меланхолічного типів, а з середнім рівнем стресостійкості з тенденцією до низького - у меланхолічно-холеричного типу.

Отже, підсумовуючи результати дослідження, робимо висновок, що з п'яти типів темпераменту, представники яких складають групу, що брала участь в дослідженні, найменш стійкою до стресу є група меланхолічно-холеричного типу.

Холерико-сангвінічний і флегматико-меланхолічний типи виявилися найстійкішими до стресових ситуацій.

Респонденти з нормальним типом темпераменту демонструють досить високий опір стресу. Більша частина $(71,4 \%)$ представників цієї групи має показник середнього рівня стресостійкості з тенденцією до високого.

Найбільш суперечливі результати були виявлені в групі досліджуваних з типом темпераменту «холерик». 50\% респондентів цього типу мають середній рівень стресостійкості з тенденцією до низького, а інші 50\% - 3 тенденцією до високого рівня стресостійкості.

Дослідивши проблему стресостійкості у студентів-психологів першого курсу і проаналізувавши наукову літературу, ми побачили, що дане питання цікавить як українських, так і зарубіжних фахівців. Особливо актуальною тема стресостійкості стала в умовах пандемії COVID-19, яка є причиною змін багатьох звичних процесів, в тому числі й учбового. За результатами дослідження не виявлено жодного респондента з високим рівнем стре- состійкості чи з низьким. У всіх досліджуваних простежується середній рівень стресостійкості: у більшості опитаних простежується середній рівень з тенденцією до високого, у решти середній рівень з тенденцією до низького рівня стресостійкості. Більшість опитаних студентів має середній рівень тривоги з тенденцією до високого чи високий рівень тривоги. Меншість має середній рівень з тенденцією до низького рівня тривоги. Результати роботи показали, що з п'яти типів особистостей за темпераментом, представники яких склали групу, що брала участь в дослідженні, найменш стійкою до стресу виявилася група меланхолічно-холеричного типу, а найбільш стійкими - групи холерико-сангвінічного і флегматико-меланхолічного типів. Перспективними напрямами роботи автори вважають встановлення наявності взаємозв'язку між рівнем стресостійкості та типом темпераменту і розробку рекомендацій щодо підвищення рівня стресостійкості.

\section{ЛІТЕРАТУРА:}

1. Куприянов Р.В., Кузьмина Ю.М. Психодиагностика стресса : практикум. Казань : КНИТУ, 2012. 212 с.

2. Зливков В.Л., Лукомська С.О., Федан О.В. Психодіагностика особистості у кризових життєвих ситуаціях. Київ : Педагогічна думка, 2016. 219 с.

3. Наугольник Л.Б. Психологія стресу : підручник. Львів : Львівський державний університет внутрішніх справ, 2015. 324 с.

4. Бужинська С.М., Скляр С.С., Даніліч-Скакун А.А. Стресостійкість студентів як складник успішності навчання у 3ВО. Габітус. 2021. № 23. С. 55-59.

5. Аймедов К.В., Кривоногова О.В., Михайлова К.Л., Потокуєв Д.О. Вплив психічного стану людини на реактивність імунної системи. Вісник морської медицини. Одеса, 2013. № 3. С. 13-17.

6. Зуйкова А. Ковид-тревога: как вернуться к нормальной жизни после пандемии. РБК. 2021. URL: http://webcache.googleusercontent.com/search? q=cache:ns-KItZA8I0J:https://trends.rbc.ru/trends/ social/60c08d459a7947542caf6113\&hl=ru\&gl= ua\&strip $=0 \& v w s r c=0$.

7. Псядло Э.М. Темперамент и характер в истории медицины и психологии : учебно-справочное пособие по курсам «Общая психология», «Дисрференциальная психология» и «Психофизиология». Изд. 4-е, доп. Одесса : «Фенікс», 2019. 394 с. 